\title{
Development of a Position-Sensing System for an LC resonating Slim Marker Using Phase Detection
}

\author{
S. Yabukami, T. Katoh, S. Hashi*, K.I. Arai, and Y. Okazaki* \\ RIEC Tohoku University, 2-1-1 Katahira, Aoba-ku, Sendai 980-8577, Japan \\ *Faculty of Engineering, Gifu University, 1-1 Yanagido, Gifu 501-1193, Japan
}

\begin{abstract}
We propose a new system for sensing the position of a wireless magnetic marker using phase detection. It consists of a resonating wireless magnetic marker, a driving coil, and pickup coils. A slim LC resonating marker (1.2 $\mathrm{mm}$ in diameter and $10 \mathrm{~mm}$ long) was fabricated and a deteactor was formed by connecting high-speed AD converters. The system has a position accuracy of around $1 \mathrm{~mm}$, and it can be used for highly accurate position sensing without magnetic shielding, because it is free from earth field noise.
\end{abstract}

Key words: wireless LC resonating magnetic marker, position sensing, driving coil, pickup coil.

\section{位相計測による微細な LC 共振型磁気マーカの位置・方向検出システム}

\author{
薮上 信 - 加藤智紀 - 枦修一郎 * ・荒井賢一・岡崎靖雄 ${ }^{*}$ \\ 東北大学電気通信研究所, 仙台市青葉区片平 2-1-1 （干 980-8577） \\ * 岐阜大学工学部，岐阜市柳戸 1-1（干 501-1193）
}

1. はじめに

生体内部や生体表面の部位の位置を磁気的な方法で精密 に計測する場合には，計測部位に貼付するマーカは電気的 引き出し線やバッテリをもたないことが望ましい. 光学的 に遮蔽された空間の位置検出に適した方法として, 永久 磁石や着磁された磁性体の位置検出方法が開発されてきた 1)-5). しかしこれらは直流磁界を計測対象としているため, 地磁気や低周波雑音の影響を受けやすい欠点がある。一 方 LC 共振回路によるマーカの位置検出システムとしては マサチューセッツ工科大学から報告がされている ${ }^{6)}$ 。しか しこれは 1 個のコイルを用いて磁気マーカの位置を大まか に計測するものであり，位置精度は議論できておらず, $\mathrm{mm}$ オーダの精密な位置検出システムではない. またマーカの 位置および方向の 5 自由度を計測することは困難である. またバッテリを内蔵したアクティブ IC タグによる位置検 出方法も提案されている ${ }^{7)}$ が，バッテリを内蔵すること による寸法や動作時間の制約や計測の時間的安定性等の問 題がある.

筆者らはこれまで磁気マーカへの電気的引き出し線が不 要であることと外来ノイズに影響を受けにくいことを両立 することを目指して，LC 共振回路によるマーカを用いた 位置検出システムを提案した. マーカの誘導電圧の振幅を 計測することにより, 直径 $5 \mathrm{~mm}$, 長さ $10 \mathrm{~mm}$ の磁気マーカ を用いて, $2 \mathrm{~mm}$ 程度の位置精度でマーカの位置が検出可能 であることを示した ${ }^{8)}$.

提案する位置検出システムで, マーカ直径を $1 \mathrm{~mm}$ 程度に 小型化し，かつ $1 \mathrm{~mm}$ 程度の位置精度で計測できれば，マー
カを注射針やカテーテル等により生体内へ挿入し，高精度 に位置が計測できるため, 医療応用の可能性が現時的課題 になると考えられる．

そこで本論文では振幅だけでなく位相も計測対象として 位置精度を向上させることを目指した. 既報 ${ }^{8)}$ においては, マーカの電気的特性やマーカと各コイルの配置によっては 振幅のみからマーカの寄与電圧を求めるだけでは不十分な 場合があった。さらに振幅のみを計測対象とする場合には 1 個のマーカあたり 2 つの周波数の信号の計測が必要であ り, 多数個のマーカの位置を検出する場合などに測定装置 が煩雑になることが考えられる.

さらに本稿では個々の検出コイルを同数の高速 A D コン バータへ並列に接続し，高速化および $\mathrm{S} \mathrm{N}$ 比を高めること を意図した。これにより生体内部や生体表面へマーカを挿 入あるいは貼付するための現実的な寸法である，直径 $1 \mathrm{~mm}$ 程度のマーカの位置および方向を計測することを目標とし た.

上記の目標に基づく位置検出システムを開発し，マーカ 用コイルとして直径 $1.2 \mathrm{~mm}$ ，長さ $10 \mathrm{~mm}$ の大きさを有する 微細なマーカを 3 次元的な $100 \mathrm{~mm}$ 程度の移動で $1 \mathrm{~mm}$ 程度の 絶対位置精度で計測可能であることを示した。またリアル タイムにマーカの位置を表示可能とした。

\section{2. 位相情報を用いた位置・方向の検出方法}

\section{1 全体の測定手順}

Fig. 1 は提案する位置検出システムを概念的に示したも のであり，励磁コイル，検出コイルおよび磁気マーカから 


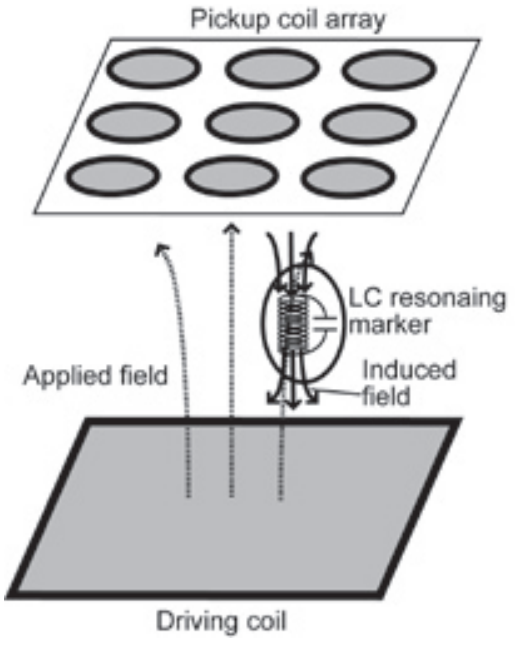

Fig. 1 Schematic diagram of the positionsensing system.

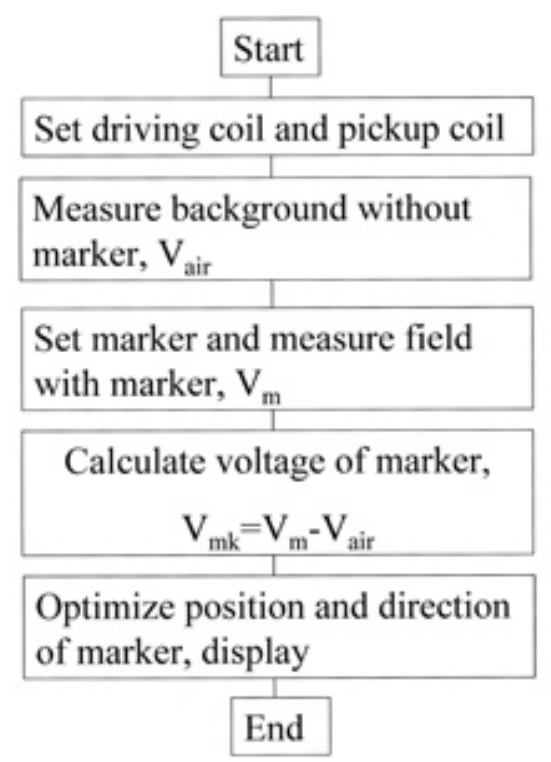

Fig. 2 Flow chart.

構成される. 本システムでは励磁コイルによりマーカの共 振周波数における交流磁界を発生させ，マーカからの誘導 磁界を検出コイルアレイを用いて計測し，マーカからの誘 導磁界をダイポール磁界と仮定してマーカの位置および方 向を最適化する.

Fig. 2 はマーカの位置および方向を求めるフローチャー トを示したものである。まずマーカを取り去った状態で, 配置した検出コイルの誘起電圧を測定し, バックグランド 電圧とする．次にマーカを配置して検出コイルの誘起電圧 を測定する．マーカの有無による誘起電圧のベクトル的な 差分を求めることで，マーカの寄与分が測定される．つぎ にマーカの位置および方向はマーカから発生する誘導磁界 がダイポール磁界に近似できることを仮定して，（1）～(3) 式により位置および方向を Gauss-Newton 法 ${ }^{9)}$ により最 適化処理する.

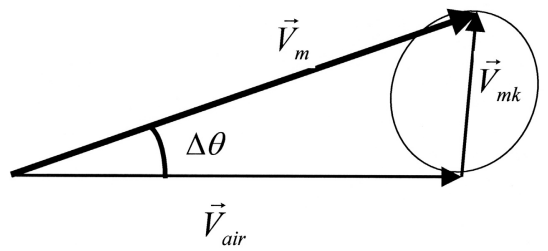

(a) Vector chart using the phase of the induced voltage

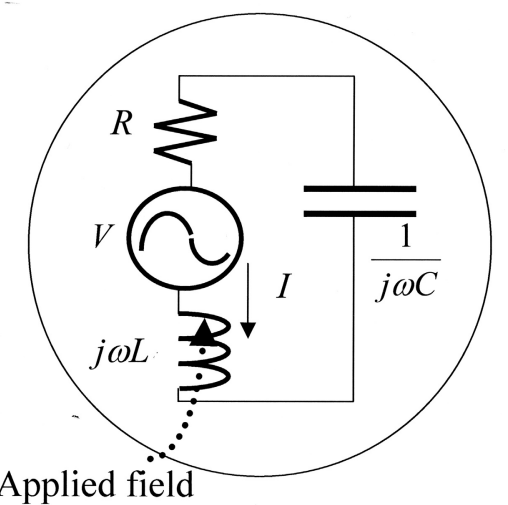

(b) Equivalent circuit of the LC resonating marker

Fig. 3 Measurement of the induced voltage using phase.

$$
\begin{gathered}
S(\vec{p})=\sum_{i=0}^{n}\left(B_{m}^{(i)}-B_{c}^{(i)}(\vec{p})\right)^{2} \\
\vec{B}_{c}^{(i)}(\vec{p})=\frac{1}{4 \pi \mu_{o}}\left\{-\frac{\vec{M}}{r_{i}^{3}}+\frac{3\left(\vec{M} \cdot \vec{r}_{i}\right) \cdot \vec{r}_{i}}{r_{i}^{5}}\right\} \\
\vec{p}=(x, y, z, \theta, \phi, M)
\end{gathered}
$$

ただし $S$ は評価值であり， $\vec{p}$ はパラメータベクトルであ る. $i$ は検出コイルの番号 $(1 \sim n), \quad \vec{B}^{(i)}{ }_{c}(\vec{p})$ は双極子磁 界を考慮した検出コイル $i$ における磁束密度の理論值, $\vec{r}$ はマーカから検出コイル $i$ への位置ベクトル, $\vec{M}$ はマー カの磁気モーメント, $(x, y, z)$ はマーカ $i$ の座標, $\theta$ は $x y$ 平面へ射影したモーメントの方向ベクトルと $\mathrm{x}$ 軸とのなす 角， $\phi$ はモーメントの方向ベクトルと $\mathrm{z}$ 軸とのな寸角， $\vec{p}$ はマーカのパラメータにより構成されるベクトル,$\alpha$ は縮 小因子である。

\section{2 位相情報を用いた計測方法}

Fig. 3 はマーカの共振周波数におけるマーカの寄与電圧 $\vec{V}_{n k}$, バックグランド電圧 $\vec{V}_{\text {ow }}$, マーカを挿入した状態での コイルの誘起電圧 $\vec{V}_{v}$ のベクトル図として表記したもので ある.また Fig. 3(b) はマーカの等価回路を模式的に示し たものである. Fig. 3(b) 中のLはコイルのインダクタンス, $\mathrm{C}$ はコンデンサのキャパシタンス，R は内部抵抗，V は外 部から与えられた交流磁界による誘起電圧を等価的な電圧 源として表記したもの，I は電圧源により回路中を流れる 誘導電流を示した。 マーカの共振周波数では Fig. 3(b) の 誘導電流 I が最大となるため, $\vec{V}_{a x}$ が最大となる．共振周波 数で計測することで最も S N 比の高い計測が可能になると ともに，1 マーカあたり 1 個の周波数でマーカの寄与電圧 


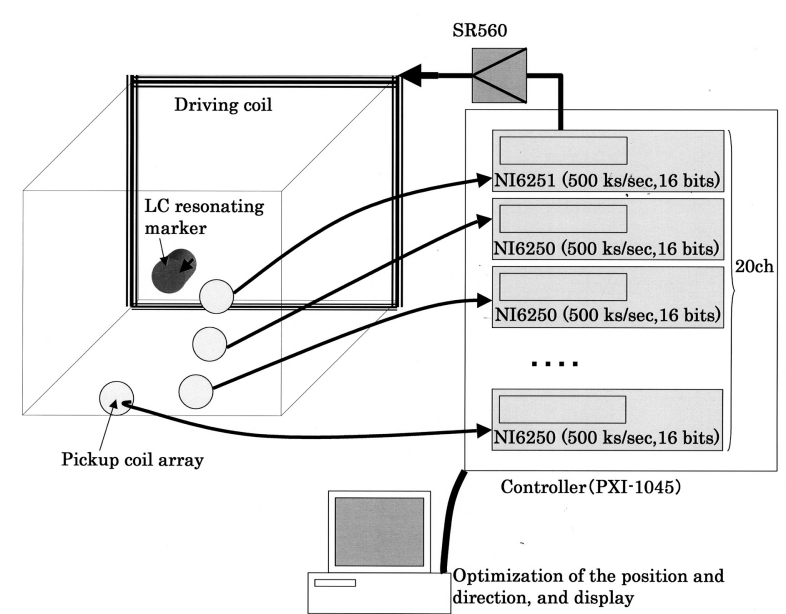

Fig. 4 Schematic diagram of the position sensing system.

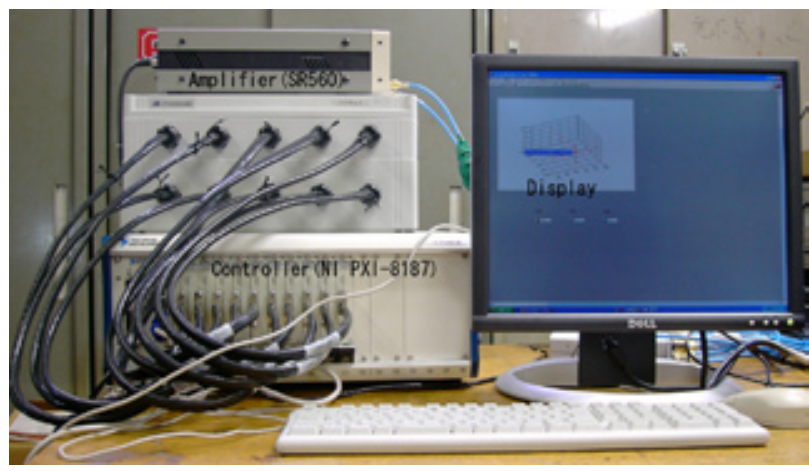

Fig. 5 Photograph of the electrical equipment.

が計測可能になると考えられる．既報 ${ }^{8)}$ では誘導電圧の振 幅を計測対象とし、誘起電圧の極大值および極小值の 2 つ の周波数成分を計測する必要があった。本稿では各検出コ イルにおいてマーカがない状態での誘起電圧の振幅，マー カをおいた状態での振幅，および両者の電圧の位相差を測 定し，(4) 式を用いてベクトル的に等価的なマーカ寄与電 圧を求めた。

$$
\vec{V}_{m k}=\vec{V}_{m}-\vec{V}_{a i r}
$$

\section{3. 位置検出システム}

Fig. 4 は試作した位置検出システムの構成を示したもの である。計測システムは励磁コイル，検出コイルアレイ (20 チャンネル), LC 共振型磁気マーカ， $\mathrm{AD}$ コンバータお よび DA コンバータ（NI PXI-6251：1台)，AD コンバータ (NI PXI-6250：9台)，制御ユニット（NI PXI-8187），プ リアンプ（SR560）から構成される。制御用プログラムは Lab VIEW ver.7.1，位置および方向の最適化処理プログラ ムはVisual C++を用いて作成した。 AD コンバータである PXI-6251 およびPXI-6250 は 500ksample/sec のサンプリ

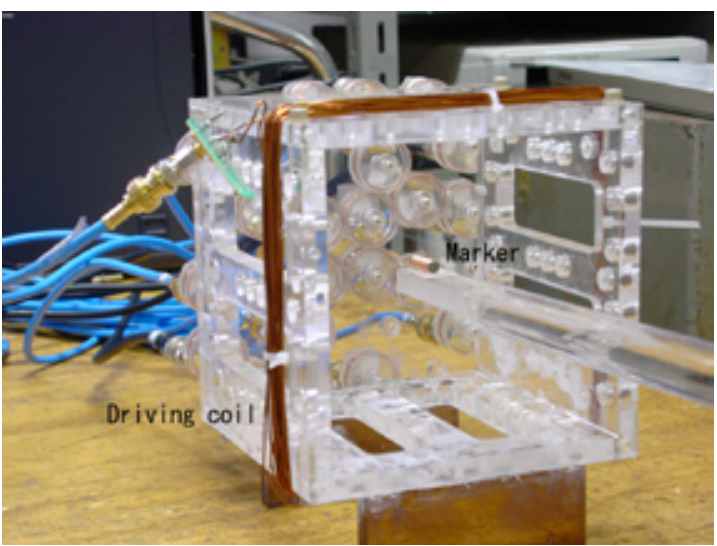

(a) Driving coil and marker

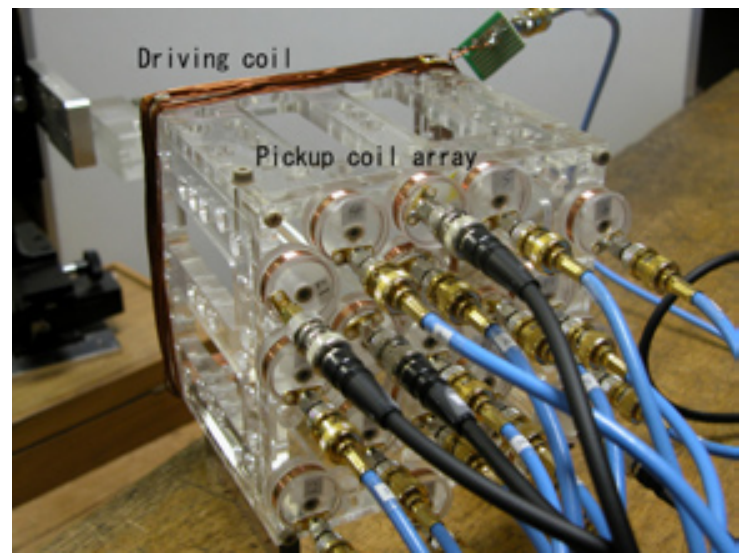

(b) Pickup coil array

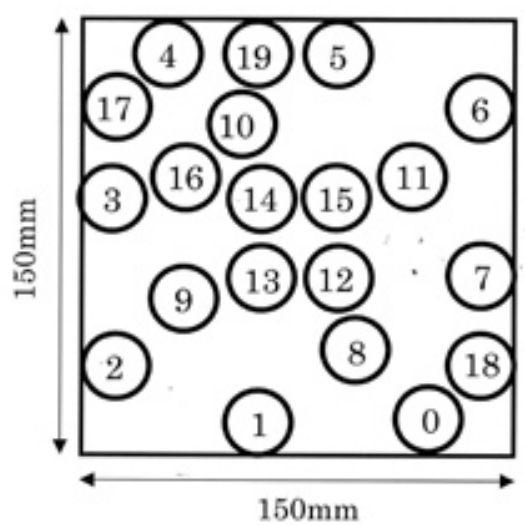

(c) Arrangement of pickup coil

Fig. 6 Arrangement of coils and marker.

ング速度で， 1 台あたり 2 チャンネルの 16 ビット信号を 計測するモードで使用し，20 チャンネルの検出コイルの 誘起電圧を並列に取得できるように構成した。励磁コイル への電圧はPXI-6251 からの出力信号をアンプを介して励 磁コイルへ接続した。すべての $\mathrm{AD}$ コンバータおよび $\mathrm{DA} コ$ ンバータはPXI システムのため相互に同期が取れており, 基準信号に対する位相差を計測可能である．LC 共振型磁 気マーカは励磁コイルと検出コイルから構成されるユニッ 卜内部に配置した．マーカの位置および方向の最適化処理 はイーサーネット接続した別のパソコン (Pentium(R)D, 


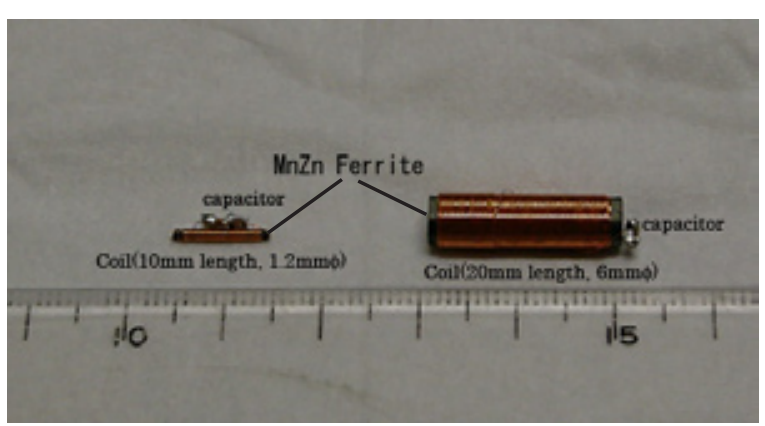

Fig. 7 Photograph of the LC resonating marker.

Table 1 Size of the marker coil.

\begin{tabular}{cccc} 
& $\begin{array}{l}\text { Diameter of } \\
\text { coil (mm) }\end{array}$ & $\begin{array}{c}\text { Length of } \\
\text { coil (mm) }\end{array}$ & $\begin{array}{c}\text { Numbers of } \\
\text { turns }\end{array}$ \\
\hline Marker 1 & 6 & 20 & 500 \\
\hline Marker 2 & 1.2 & 10 & 77 \\
\hline
\end{tabular}

3. 20GHz）で演算し，マーカ位置を画面上に表示させた.

Fig. 5 は計測システムに用いた PXI 制御コントローラ (AD コンバータと DA コンバータを内蔵)，プリアンプおよ びディスプレイの写真である. Fig. 6 は励磁コイル，検出 コイル，マーカの写真である. Fig. 6(a) は励磁コイルと マーカ配置を示したものである. 励磁コイルおよび検出 コイルはアクリルで作成した一辺 $150 \mathrm{~mm}$ の立方体に配置 し, 励磁コイルと検出コイルの面は $150 \mathrm{~mm}$ の距離で対向 させた. 励磁コイルは一辺約 $150 \mathrm{~mm}$ の正方形であり, 直 径 $1.0 \mathrm{~mm}$ の銅線を 20 ターン施した. Fig. 6(b) は検出コ イルアレイの写真を示し，Fig. 6(c) は検出コイルの配置を 示したものである。検出コイルは線径 $0.2 \mathrm{~mm}$ の銅線を直径 $23 \mathrm{~mm}, 125$ ターンのコイルに施し，同一平面状に 20 個 配置した. 丸枠は実際の検出コイルの寸法を示しており, 丸枠内の数值は検出コイルの番号を示している. 検出コイ ルの配置位置は一辺 $150 \mathrm{~mm}$ の立方体内部において局所解に よる影響が十分小さくなることを意図して設計した。

Fig. 7 は試作した LC 共振型マーカの写真を示したもの である。マーカはコイル，コンデンサを半田で直列に接 続して作成した。マーカは 2 種類作成し寸法は Table 1 に 示す. マーカ 1 は直径 $5 \mathrm{~mm}$, 長さ $20 \mathrm{~mm}$ の $\mathrm{MnZn}$ フェライト （TDK 株式会社製 $\mathrm{EE}$ シリーズ）の周囲に直径 $0.1 \mathrm{~mm}$ の銅線 を 500 ターン巻いて外形寸法が長さ $20 \mathrm{~mm}$, 直径約 $6 \mathrm{~mm}$ と した. $90 \mathrm{kHz}$ におけるインダクタンスは約 $5.6 \mathrm{mH}$ であった. $90 \mathrm{kHz}$ における性能指数は約 60 であった。コンデンサは $1 \mathrm{nF}$ のチップコンデンサ（ROHM 社製 $\mathrm{MCH}$ シリーズ）を使用 した。マーカ 2 は直径 $1 \mathrm{~mm}$, 長さ $10 \mathrm{~mm}$ の MnZn フェライト の周囲に直径 $0.1 \mathrm{~mm}$ の銅線を 1 層（77 ターン）施したも のである。それぞれマーカの共振周波数は約 $90 \mathrm{kHz}$ に設定 した。共振周波数における性能指数は約 10 であった。今 回は使用したチップコンデンサの寸法が大きく，マーカ全 体として直径 $1 \mathrm{~mm}$ 程度にはなっていないが, 市販品の微細 なチップコンデンサを適用することでマーカ全体の微細化 は可能と考えている．マーカは非導体による 3 軸スキャナ により移動させた.

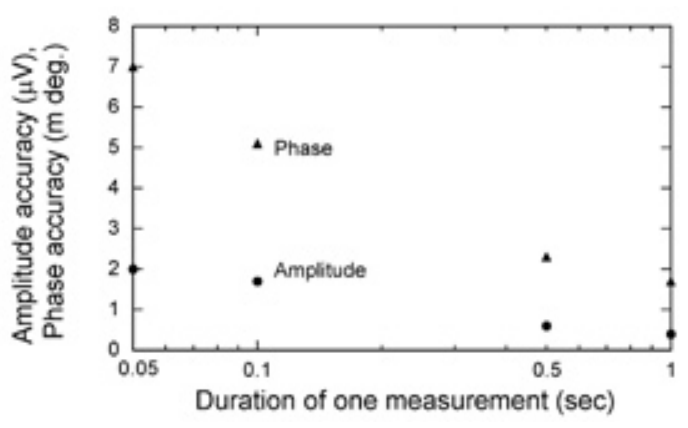

(a) Obtained accuracy

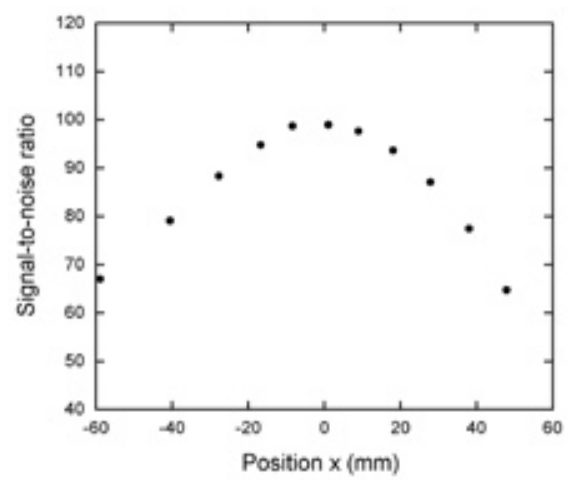

(b) Obtained signal-to-noise ratio

Fig. 8 Measured basic characteristics.

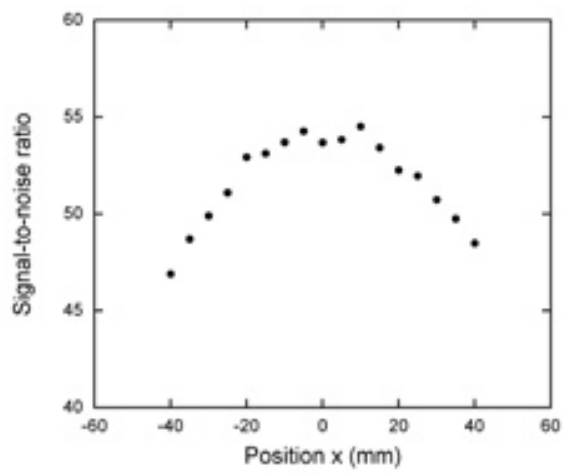

(a) Signal-to-noise ratio

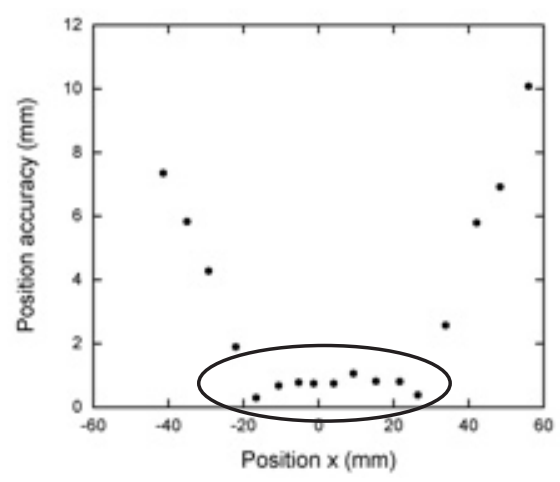

(b) Position accuracy

Fig. 9 Relation between the $\mathrm{SN}$ ratio and the position accuracy obtained by using the network analyzer.

\section{4. 実測結果}

\section{1 振幅および位相の測定確度}

Fig. 8 は本計測システムにおける振幅および位相の計測 確度を測定時間に対して示したものである。それぞれは 


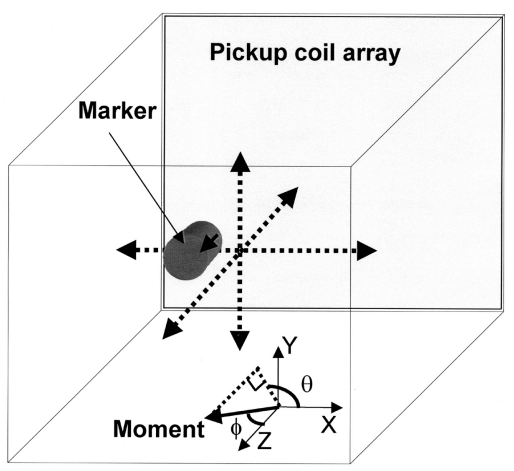

(a) Positioning of marker

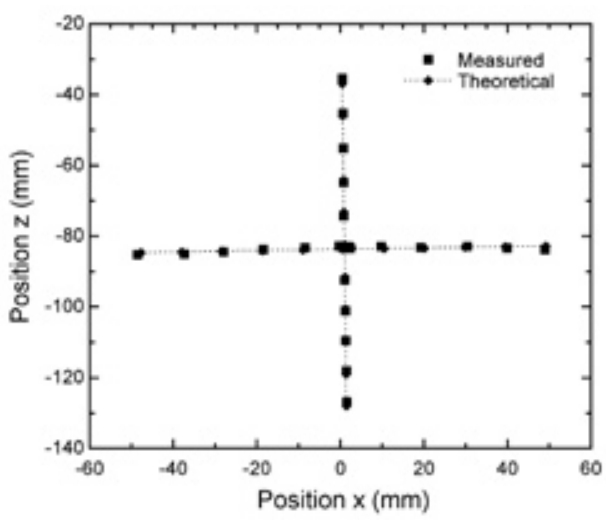

(b) Position in $\mathrm{x}^{-} \mathrm{z}$ plane

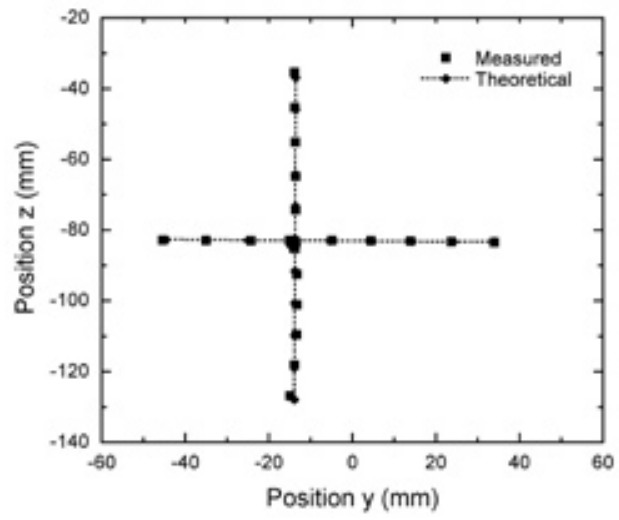

(c) Position in $y^{-} z$ plane

1000 回の測定における標準偏差から求めた。計測時間が 長いほど振幅および位相の計測確度は高感度化し，ほぼ平 均化回数の $1 / 2$ 乗に反比例した. 例えば測定時間が 0.1 秒 $(10 \mathrm{~Hz})$ であれば, 振幅確度は約 $1.7 \mu \mathrm{V}$, 位相確度は $5.1 \mathrm{~m}$ 度となった. Fig. 8(b) はこの測定装置を用いて, 検出コ イルからの距離が $80 \mathrm{~mm}$ の地点に微細なマーカ 2 を配置し た時の各検出コイルの平均的な信号レベルと Fig. 8 の振 幅角度との SN 比を求めたものである. SN 比は最大で 100 程度得られた。

Fig. 9(a) は市販のネットワークアナライザ（MS4630B） を本論文で使用した $\mathrm{AD}$ コンバータの代わりに用い，マー カ 2 を用いて，上記と同一構成での SN 比を比較したもの である. Fig. 9(b) はその際のマーカの絶対位置精度を示 している.ネットワークアナライザの RBW（レゾリューショ ンバンド幅) は $100 \mathrm{~Hz}$ ，平均化回数は 10 回とした. Fig. 9(b)の中心付近である約 $40 \mathrm{~mm}$ の範囲において $1 \mathrm{~mm}$ 以内の

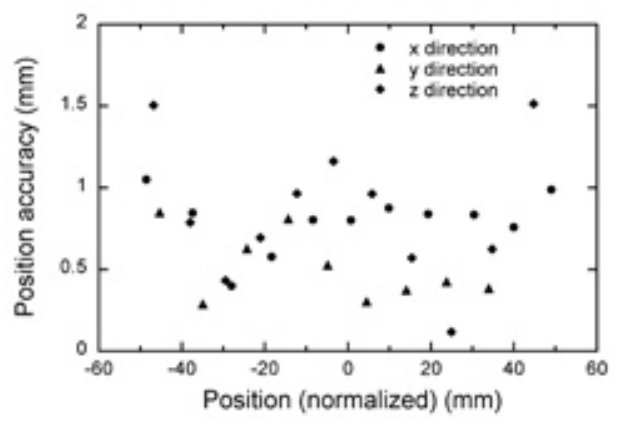

(d) Position accuracy

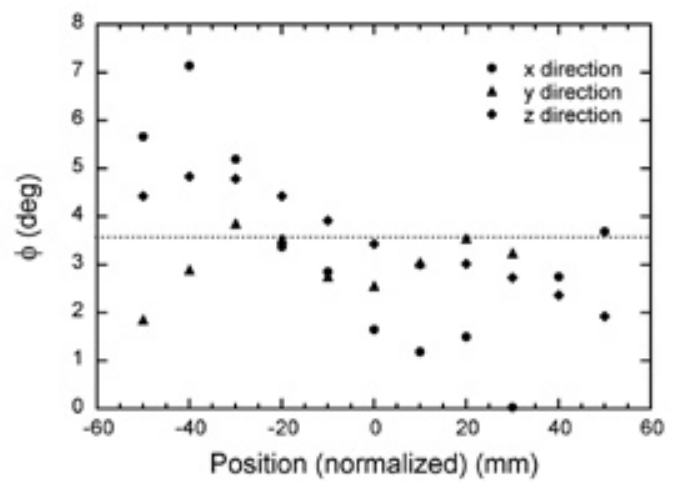

(e) Accuracy of direction

Fig. 10 Profile of marker 1 (coil diameter $=6 \mathrm{~mm}$, length $=20 \mathrm{~mm}$ ).

絶対位置精度が得られており，それに対する SN 比は約 50 以上であった。この SN 比は本稿の検出器を用いた場合の SN 比を下回った.

以上から本論文で試作した計測部を用いて，1mm 程度の 絶対位置精度を得る際に必要な計測確度が得られたと考え られる。

\section{2 磁気マーカの位置および方向}

Fig. 10 はマーカ 1 の位置および方向を示したものであ る. マーカは Fig. 7 で示した直径 $6 \mathrm{~mm}$, 長さ $20 \mathrm{~mm}$ のマー カである. 位置は検出コイルからの距離が $80 \mathrm{~mm}$ の位置を 基準にして，x 軸，y 軸， $\mathrm{z}$ 軸のそれぞれの方向へ $10 \mathrm{~mm}$ 刻 みで約 $100 \mathrm{~mm}$ 移動させた。ただし検出コイルの座標系と マーカ移動用マイクロメータの座標系は一致していないた め, 得られたマーカの座標はわずかに傾いている。 マーカ 用コイルの法線方向は図中の $\mathrm{y}$ 軸方向とほぼ平行になるよ うに配置し、励磁コイルによる発生磁界とマーカの法線方 向がほぼ平行となる基本的な配置において位置精度を検討 した。実際の用途では励磁コイルは 2 軸あるいは 3 軸成 分とし、必要な $\mathrm{S} \mathrm{N}$ 比を得るように設計する必要がある. 計測周期は $1 \mathrm{~Hz}$ とした。座標軸は Fig. 10(a) 中に示した。 Fig. 10(a) にはマーカの方向角を定義した。 $\theta$ はマーカの 方向ベクトル（マーカコイルの法線方向ベクトル）を $\mathrm{xy}$ 平面へ射影したものと $\mathrm{x}$ 軸とのな寸角であり、 $\phi$ はマーカ の方向ベクトルと z 軸とのなす角である。Fig. 10(b) は xz 平面内での位置を示したものであり, Fig. 10(c) はyz 平 面内での位置を示した。は実測值であり, 破線は理論值 である。破線は実測值の軌跡と平行かつほぼ対応するよう 


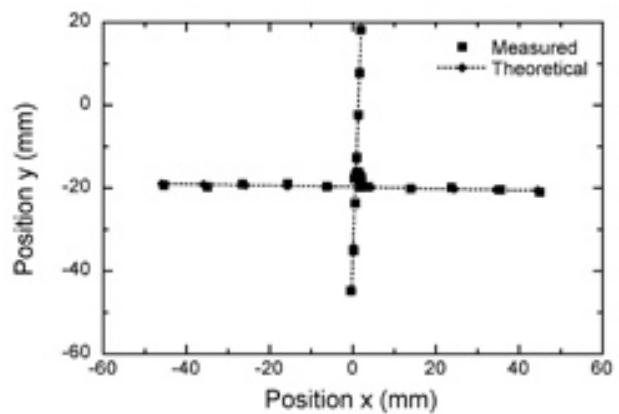

(a) Position in $x^{-} z$ plane

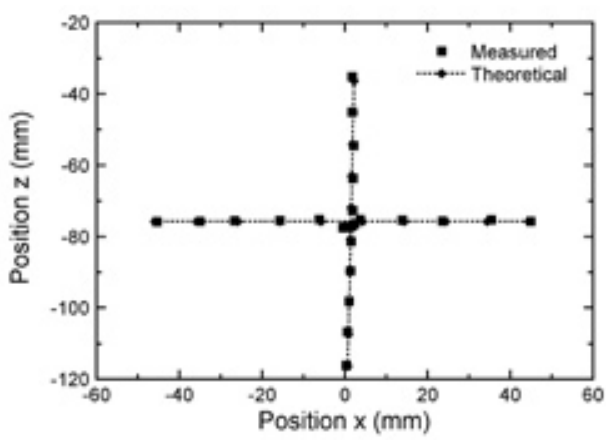

(b) Position in $x^{-} z$ plane

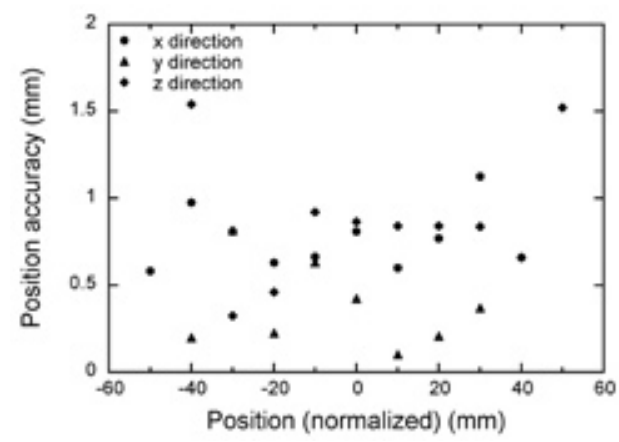

(c) Position accuracy

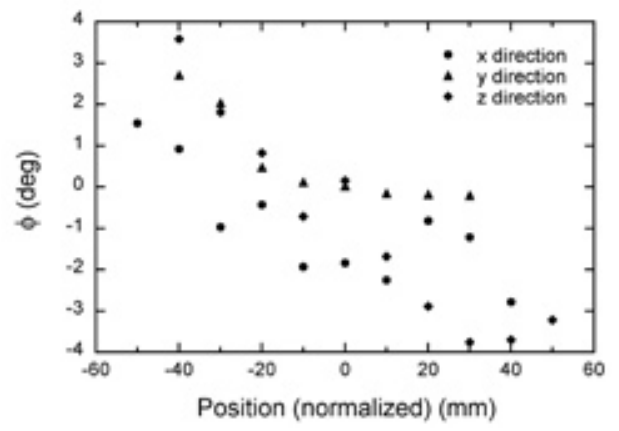

(d) Direcion of marker

Fig. 11 Profile of slim marker (coil diameter $=1.2 \mathrm{~mm}$, length=10 $\mathrm{mm}$ ).

な直線で表記した。さらに破線の中の、は $10 \mathrm{~mm}$ 刻みのマー カの位置を表し，マーカの理論的な位置を示した. Fig. 10(b) および Fig. 10(c) からマーカの位置は概ね正しく計 測されていると判断される. Fig. 10(d) は絶対位置精度を

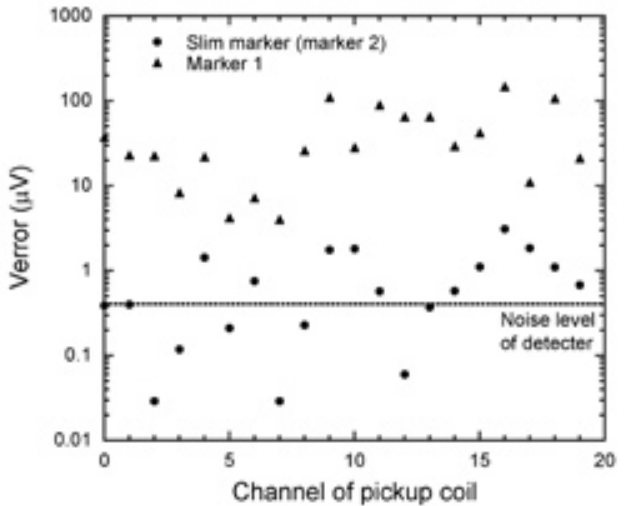

Fig. 12 Error volage.

示した. 絶対位置精度は Fig. 10(a)および Fig. 10(b) にお けるロと〉の 3 次元位置の距離で定義した。横軸は基準 位置に対しての移動距離を正規化して示した．Fig. 10(d) によれば検出コイルの面から最大で $130 \mathrm{~mm}$ の距離以内で $1.5 \mathrm{~mm}$ 以内の絶対位置精度が得られた。全体の約 $88 \%$ の 測定点で $1 \mathrm{~mm}$ 以内の絶対位置精度が得られた。端部ほど位 置精度が悪化している主要因はマーカから検出コイルアレ イを見た立体角が小さくなっていることと，検出コイルの 個数が十分に確保できなかった領域があることと考えられ る。なお、マーカへ鎖交する磁束の低下等による S N 比の 低下はこの実験した範囲内で最小でも約 3600 であり、こ れは位置精度に換算すると $100 \mu \mathrm{m}$ 以内であるため、影響 は小さいと考えられる。

Fig. 10(e) にはマーカの方向角を示した. $\phi$ は方向ベク トルと $\mathrm{z}$ 軸とのなす角である。実験した配置はコイルの法 線成分がほぼ $\mathrm{y}$ 軸と平行であり， $\theta$ は定義できないため $\phi$ のみ記載した。横軸は基準点からの移動距離として表記し た。 $\phi$ はおおむ称 0 度近辺の值が得られた。絶対角度精度 は土 4 度以内であった。

Fig. 11 は微細なマーカ 2 を用いて得られた位置および 方向を示したものである. マーカの移動方法は Fig. 10 と 同一とした。計測周期は $1 \mathrm{~Hz}$ とした。Fig. 11(a) はxy 平 面内のマーカの位置を示したものであり，Fig. 11(b) はxz 平面内でのマーカの位置を示した。マーカの位置は概ね正 確に計測された。Fig. 11(c) は絶対位置精度を示した。位 置精度は実験した範囲で $1.6 \mathrm{~mm}$ 以内であった。全測定点の 中の約 $91 \%$ の点で絶対位置精度は $1 \mathrm{~mm}$ 以内となり，概水 目標を達成したと考えられる.Fig. 11(d) は角度のプロファ イルを示したものである。角度精度は概社 4 度以内で あった。

\section{3 位置精度についての考察}

Fig. 12 は 2 種類のマーカを基準点（検出コイルアレ イからの距離は約 $80 \mathrm{~mm}$ ) に配置した場合における各検出 コイルに対して誤差電圧を示したものである。誤差電圧 $V_{\text {eror }}$ は（5）式によって算出した。 


$$
V_{e r o r}^{(i)}=V_{m k}^{(i)}-V_{c}^{(i)}
$$

ただしは $V_{m k}$ マーカ寄与電圧の実測值, $V_{c}$ は最適化処理さ れた位置および方向を（2）式一代入して得られた磁束密度 を電圧に換算した計算值，i は検出コイルの番号である.

Fig. 12 によればマーカ 1 （コイル直径 : 6mm，コイル長 さ: $20 \mathrm{~mm})$ における誤差電圧は測定器のノイズレベルに比 較して十分に大きく，このマーカを用いた位置精度はマー カおよび検出コイルの寸法効果によりダイポール磁界から の誤差が主要因と考えられる.

一方微細なマーカ 2 (コイル直径 $: 1.2 \mathrm{~mm}$ ，コイル長 さ: $10 \mathrm{~mm})$ における誤差電圧は測定器のノイズレベルに比 較して若干大きいものの, ほぼ同程度のオーダであった. このためこのマーカにおける誤差要因はマーカおよび検出 コイルの寸法効果と計測器のノイズがともに寄与している と考えられる.

\section{5. まとめ}

1. LC 共振型磁気マーカの位置検出システムで, 位相情報 を用いたリアルタイム動作による位置検出システムを開発 した.

2. 検出コイルからの最大距離 $130 \mathrm{~mm}$, 一辺 $100 \mathrm{~mm}$ の立方体 内部において直径 $6 \mathrm{~mm}$, 長さ $20 \mathrm{~mm}$ のマーカで絶対位置精 度は $1.5 \mathrm{~mm}$ 以内を得た。全測定点の約 $88 \%$ の点で絶対位 置精度は $1 \mathrm{~mm}$ 以内であった。

3. マーカコイルの直径が約 $1.2 \mathrm{~mm}$, 長さが $10 \mathrm{~mm}$ のマーカ を用いて上記の範囲において絶対位置精度は $1.6 \mathrm{~mm}$ 以内で あった。全測定点の約 $91 \%$ の点で絶対位置精度は $1 \mathrm{~mm}$ 以 内であった。

4. 直径 $6 \mathrm{~mm}$ のマーカを用いた場合の位置検出時の誤差要 因は主としてマーカ用コイルおよび検出コイルの寸法効果 によりダイポール磁界から実際の磁界分布が誤差を持って いることが考えられる. 微細なマーカ (コイル直径 $: 1.2 \mathrm{~mm}$ ) においては寸法による影響と検出器のノイズに起因すると 考えられる.

\section{謝辞}

PXI 計測システムの作製にご協力いただいた株式会社 CPI テクノロジーズ 高野卓雄氏, 高野卓大氏, 鎌田 勇 氏に感謝いたします。本研究の一部は総務省の「戦略的 情報通信研究開発推進制度」（5E5 番 126 号）の助成によ り行った。本研究の一部は新エネルギー・産業技術総合 開発機構の「産業技術研究助成事業」（プロジェクト ID : 03A47063a）により行った。

\section{References}

1) F. Grant, G.West, Interpretation Theory in Applied Geophysics. New York: McGraw-Hill, 1965, pp. 306-381.

2) S.V. Marshall, Vehicle Detection Using a Magnetic Field Sensor, IEEE Trans. Vehicular Technology, vol. VT-27, pp. 65-68, (1978).

3) W.M. Wynn, C.P. Frahm, P.J. Carroll, R.H. Clark, J. Wellhoner, M.J. Wynn, Advanced Superconducting Gradiometer/Magnetometer Arrays and A Novel Signal Processing Technique, IEEE Trans. Magn., vol. MAG-11, pp. 701-707,(1974).

4) J.E. Mcfee, Y. Das, Determination of the Parameters of a Dipole by Measurement of its Magnetic Field, IEEE Trans. Antennas and Propagation, vol. AP-29, pp. 282-287(1981).

5) S. Yabukami, K. Arai, H. Kanetaka, S. Tsuji, and K.I. Arai, Journal of the Magnetics Society of Japan, vol. 28, pp. 711-717 (2004)

6) J.A. Paradiso, K. Hsiao, J. Stricken, J. Lifton, A. Adler, IBM Systems Journal, vol. 39, No. 3\&4, pp. 892-914 (2000).

7) S. Watanabe, S. Nishiyama, N. Koshizuka, and K. Sakamura, MWE 2003 Microwave Workshop, pp.245-250 (2003).

8) S. Yabukami, S. Hashi, Y. Tokunaga, T. Kohno, K.I. Arai, and Y. Okazaki, Journal of the Magnetics Society of Japan, vol. 28, pp. 877-885 (2004).

9) Nakagawa, Y. Koyanagi, Experimental Data Analysis by the least square method ,p.95-99, The University of Tokyo Press (1982).

2005 年 10 月 19 日受理, 2005 年 12 月 16 日採録 